\title{
Analysis of the coding sequence and expression of the coiled-coil $\alpha$-helical rod protein 1 gene in normal and neoplastic epithelial cervical cells
}

\author{
JOANNA PACHOLSKA-BOGALSKA ${ }^{1}$, MAGDALENA MYGA-NOWAK ${ }^{2}$, KATARZYNA CIEPŁUCH ${ }^{3}$, \\ AGATA JÓZEFIAK ${ }^{4}$, ANNA KWAŚNIEWSKA ${ }^{5}$ and ANNA GOŹDZICKA-JÓZEFIAK ${ }^{3}$
}

\begin{abstract}
${ }^{1}$ Department of Animal Physiology and Development, Adam Mickiewicz University, 61-614 Poznan; ${ }^{2}$ Department of Biotechnology and Microbiology, Jan Dlugosz University, 42-218 Czestochowa; ${ }^{3}$ Department of Molecular Virology, Adam Mickiewicz University, 61-614 Poznan; ${ }^{4}$ Genesis Center for Medical Genetics, 60-601 Poznan;

${ }^{5}$ Department of Gynaecology and Obstetrics, Medical University of Lublin, 20-081 Lublin, Poland
\end{abstract}

Received October 20, 2011; Accepted December 2, 2011

DOI: $10.3892 / \mathrm{ijmm} .2012 .877$

\begin{abstract}
The role of the CCHCR1 (coiled-coil $\alpha$-helical rod protein 1) protein in the cell is poorly understood. It is thought to be engaged in processes such as proliferation and differentiation of epithelial cells, tissue-specific gene transcription and steroidogenesis. It is supposed to participate in keratinocyte transformation. It has also been found that this protein interacts with the E2 protein of human papilloma virus type 16 (HPV16). The oncogenic HPV forms, such as HPV16, are known to be necessary but not sufficient agents in the development of cervical carcinoma. In the present study, the CCHCRI gene coding sequence and its expression was analyzed in normal, precancerous and cervical cancer cells. Changes in the noncoding region were found in $20.3 \%$ of the examined probes from women with cervical cancer or precancerous lesions and in $16.67 \%$ of the control probes. Most of the detected changes were single nucleotide polymorphisms (SNPs). Changes in the coding region were found in $22.8 \%$ of the probes with cervical cancer and in $16.67 \%$ of the control probes and all of them were SNPs. The level of CCHCRI transcripts was determined using the real-time PCR method and the highest gene expression was detected in the H-SIL group and slightly decreased in the cervical carcinoma cells, compared with the
\end{abstract}

Correspondence to: Dr Joanna Pacholska-Bogalska, Department of Animal Physiology and Development, Adam Mickiewicz University, ul. Umultowska 89, 61-614 Poznan, Poland

E-mail: pacholsk@amu.edu.pl

Abbreviations: CCHCR1, coiled-coil $\alpha$-helical rod protein 1; HPV, human papilloma virus; H-SIL, high-grade squamous intraepithelial lesions; L-SIL, low-grade squamous intraepithelial lesions; SNP, single nucleotide polymorphism; SSCP, single stranded conformation polymorphism

Key words: cervical carcinoma, human papilloma virus, coiled-coil $\alpha$-helical rod protein 1 control probes. It suggests that CCHCR 1 could have a role in the process of cervical epithelial cell transformation, but this suggestion must be confirmed experimentally.

\section{Introduction}

The oncogenic human papilloma virus (HPV) forms (HPV16, 18,31 and 33) are etiological agents in the development of cervical carcinoma. However, the cell factors engaged in the process of the cancer development in cervical epithelial cells are poorly known $(1,2)$.

Using the yeast two-hybrid system and the cDNA library from normal epithelial tissue, we have previously shown that the protein CCHCR1 (coiled-coil $\alpha$-helical rod protein 1) interacts with the $\mathrm{E} 2$ protein of human papillomavirus type 16 , which suggests its important role in the epithelial tissue function (3).

CCHCR1 is a protein of unknown role in the cell. This protein shows little homology with known proteins (4). Secondary structure predictions for the CCHCR 1 protein suggests that it contains several segments of coiled-coil structure. CCHCR1 is either a nuclear or cytoplasmic protein, but was also found in mitochondria and endosomes (5), and also in keratinocyte pseudopodia in vitro. Its nuclear localization and possibility for the dimerization and interactions with DNA (via a leucine zipper motif) suggests a role of CCHCR1 in regulating cell differentiation or proliferation (6-8). CCHCR1 was found to be overexpressed in keratinocytes at psoriatic skin lesions, whereas in paired samples from normal appearing skin it was barely detectable. Therefore it was suggested that it could be involved in psoriasis susceptibility (4), but the connection of changes in the CCHCRI gene with psoriasis is still the subject of investigations $(6,9)$. Functional analysis in the transgenic mouse model revealed that the CCHCR1 psoriatic allele is not enough to cause the psoriatic disease and additional genes or environmental stimulation is necessary to trigger off the psoriatic phenotype in the mouse $(10,11)$.

The $C C H C R 1$ gene, encoding a 782 amino acid protein, is located on chromosome 6 and consists of 18 exons $(5,12)$. The 
CCHCR 1 gene is highly polymorphic. It has 2 transcription start sites, which are located 79 and $430 \mathrm{bp}$ upstream of the translation start site (ATG) in exon 2. Alternative transcription of the 5'-untranslated region can be regulated in a tissue by alternative usage of promoters (5).

The aim of the present study was the analysis of the CCHCRl gene in precancerous and cancer lesions and in HPV positive and negative dysplasia cells.

\section{Materials and methods}

Material. The investigations were performed using cervical cancer specimens obtained from women who were subjected to surgery during 2004-2008, because of histologically confirmed neoplastic lesions. The study material consisted of 73 patients that underwent surgeries due to: squamous cell carcinoma of the cervix or adenocarcinoma of the cervix and low- and high-grade squamous intraepithelial lesions. In respect to the differentiation of the neoplastic cells, the following groups of patients were identified according to the WHO classification system: G1 $(n=10), G 2(n=16)$ and G3 ( $n=13)$ (Table I). According to FIGO clinical staging, 14 patients were classified as stage 0 (carcinoma in situ), 14 as IA, 22 as IB and 3 as IIA. The patients were between 39 and 61 years of age (mean 54.3). All patients underwent surgical procedures at the Department of Gynaecology and Obstetrics of the Medical University of Lublin. The control group was comprised of normal tissue of the uterine cervix obtained from 18 patients, 40-72 years of age, who underwent surgical treatment for uterine myomas.

Approvals obtained from the local Ethics Committee of Medical Universities in Lublin enabled us to collect cervical cancer specimens.

DNA isolation. Genomic DNA was isolated from tissue samples using the QIAamp DNA Mini kit (Qiagen) according to the manufacturer's indications.

HPV analysis. Genomic DNA was used for amplification by PCR with two specific primer pairs complementary to the HPV genome, universal for 33 types of HPV viruses: MY09, 5'-CGTCCMARRGGAWACTGATC-3' and MY11, 5'-GCMCAGGGWCATAAYAATGG-3'; for HPV 16E7/16A, 5'-ATAATATAAGGGGTCGGTGG-3' and E7/16B 5'-CATTTTCGTTCTCGTCATCTG-3'; for HPV18 -ME18A, 5'-CACGGCGACCCTACAAGCTACCTG-3' and ME18B, 5'-TGCAGCACGAATTGGCACTGGCCTC-3'. PCR reactions were performed in a total volume of $20 \mu 1$. The final mixture contained $1 \mu \mathrm{M}$ primers, $200 \mu \mathrm{M}$ dNTPs, $1 \mathrm{X}$ PCR buffer $\left(10 \mathrm{mM}\right.$ Tris- $\mathrm{HCl}, \mathrm{pH} 8.8$ at $25^{\circ} \mathrm{C}, 1.5 \mathrm{mM} \mathrm{MgCl}_{2}$, $50 \mathrm{mM} \mathrm{KCl}, 0.1 \%$ Triton $\mathrm{X}-100)$ and $1 \mathrm{U} / 25 \mu 1$ mixture of Taq polymerase (Fermentas). The samples were amplified for 35 cycles. Each cycle consisted of the following steps: denaturation at $95^{\circ} \mathrm{C}$ for $1 \mathrm{~min}$ (first cycle for $90 \mathrm{sec}$ ), annealing at $50^{\circ} \mathrm{C}$ for primer pairs $\mathrm{MY} 09 / 11,59^{\circ} \mathrm{C}$ for primer pairs $\mathrm{E} 7 / 16 \mathrm{~A}-\mathrm{E} 7 / 16 \mathrm{~B}$ and $55^{\circ} \mathrm{C}$ for primer pairs $\mathrm{ME} 18 \mathrm{~A} / \mathrm{B}$, and extension at $72^{\circ} \mathrm{C}$ for $1 \mathrm{~min}$. The reaction was performed in a DNA thermal cycler (Biometra). The amplification products were then analyzed on a $2 \%$ agarose gel with the addition of ethidium bromide in a UV transilluminator.
Table I. The WHO and FIGO classification of patients with tumors of the uterine cervix.

\begin{tabular}{lr}
\hline FIGO classification & \\
0 & 14 \\
IA & 14 \\
IB & 22 \\
IIA & 3 \\
Total & 53 \\
WHO classification & \\
G1 & 10 \\
G2 & 16 \\
G3 & 13 \\
Total & 39
\end{tabular}

Squamous cell carcinoma

Keratizing $\quad 22$

Non-keratizing $\quad 10$

Basaloid 4

Total $\quad 36$

Adenocarcinoma

Endocervical 1

Endometroid 1

Clear cell

Total

CCHCRl gene polymorphism analysis by PCR-SSCP and sequencing methods. Genomic DNA was used for amplification by PCR with two specific primers pairs complementary to fragments of the $C C H C R l$ gene (sequence and localization of primers are provided in Table II). The PCR reactions were performed in a total volume of $20 \mu \mathrm{l}$. The final mixture contained $1 \mu \mathrm{M}$ primers, $200 \mu \mathrm{M}$ dNTPs, 1X PCR buffer $(750 \mathrm{mM}$ Tris- $\mathrm{HCl}$, $\mathrm{pH} 8.8$ at $25^{\circ} \mathrm{C}, 200 \mathrm{mM}\left(\mathrm{NH}_{4}\right) \mathrm{SO}_{4}, 0.1 \%$ Tween-20), $1.5 \mathrm{mM}$ $\mathrm{MgCl}_{2}$ and $1 \mathrm{unit} / 25 \mu \mathrm{l}$ mixture of Taq polymerase (Fermentas). The samples were amplified for 35 cycles. Each cycle consisted of the following steps: denaturation at $95^{\circ} \mathrm{C}$ for $1 \mathrm{~min}$ (first cycle for $90 \mathrm{sec}$ ), annealing at proper temperature (Table III) for $30 \mathrm{sec}$ and extension at $72^{\circ} \mathrm{C}$ for $1 \mathrm{~min}$. The reaction was performed in a DNA thermal cycler (Biometra). Products of amplification were analyzed on a $2 \%$ agarose gel with addition of ethidium bromide in a UV transluminator. PCR products longer than 250 nucleotides were digested with endonucleases (Table II) before SSCP. Products of each PCR reaction (10 $\mathrm{ml}$ reaction mixture) were denatured chemically with formamide and thermically at $95^{\circ} \mathrm{C}$ for $15 \mathrm{~min}$. Subsequently, denaturation samples were placed on ice. They were electrophoresed on a $10 \%$ polyacrylamide gel with $0.5 \mathrm{X}$ TBE buffer in $200 \mathrm{~V}$ for $12 \mathrm{~h}$, stained with silver salts, and dried. PCR products were purified with a PCR purification mini kit (Qiagen) and then sequenced.

CCHCRl gene expression analysis. Cervical carcinoma, precancerous (L-SIL and H-SIL) and control tissues, collected during planned gynecological operations, were immediately put in RNAlater ${ }^{\mathrm{TM}}$ RNA stabilization reagent (Qiagen). 
Table II. Primers used to PCR-SSCP study of the CCHCRI gene.

\begin{tabular}{|c|c|c|c|c|c|}
\hline Exon & $\begin{array}{l}\text { Region of amplification } \\
\text { (according to AB088104) }\end{array}$ & $\begin{array}{l}\text { Fragment } \\
\text { length (nt) }\end{array}$ & $\begin{array}{c}\text { Primer } \\
\text { sequence } 5^{\prime} \rightarrow 3^{\prime}\end{array}$ & $\begin{array}{c}\text { Annealing } \\
\text { temperature }\left({ }^{\circ} \mathrm{C}\right)\end{array}$ & $\begin{array}{c}\text { Restriction } \\
\text { enzyme }\end{array}$ \\
\hline 1a & $91-512$ & 422 & $\begin{array}{l}\text { CCACTATGTGTTAGGACTCGAG } \\
\text { GATTCTGGGCAGTGCCTTTACC }\end{array}$ & 56.0 & $P v u \mathrm{II}$ \\
\hline $1 b$ & $765-1174$ & 410 & $\begin{array}{l}\text { GTGTCTTTGTTTCTCCTCTTGTCC } \\
\text { GAAAACGGCGTGGATGGATCCC }\end{array}$ & 57.0 & AluI \\
\hline 2 & $812-1170$ & 359 & $\begin{array}{l}\text { CAGAATCTAGAGCCTTCAAATAATGTG } \\
\text { ACGGCGTGGATGGATCCCTA }\end{array}$ & 55.5 & $A l u \mathrm{I}$ \\
\hline 3 & $3071-3422$ & 372 & $\begin{array}{l}\text { ACCTGCACTAACCTGTCTTTGA } \\
\text { AATCCTTTCTACCCCTGCATTC }\end{array}$ & 53.0 & Pst $\mathrm{I}$ \\
\hline $4 / 5$ & $6760-7204$ & 445 & $\begin{array}{l}\text { GAGCCCCСТCTTCTTTCCGC } \\
\text { CACAGATACATTCCTGCACCCTC }\end{array}$ & 57.5 & Pst $\mathrm{I}$ \\
\hline 6 & $7317-7471$ & 155 & $\begin{array}{l}\text { GGCTGCTTTCCTCTGCCCGC } \\
\text { GGGTCTGGGGGTTGGGCTGT }\end{array}$ & 60.0 & - \\
\hline 7 & 7666-7862 & 197 & $\begin{array}{l}\text { TTCTCCСACTCСТTCТСССТC } \\
\text { CGGGAGAAAAGAGAGTGCAGTG }\end{array}$ & 56.5 & - \\
\hline 89 & $9153-9522$ & 370 & $\begin{array}{l}\text { GCCCAGCTCTCTCTCСТCC } \\
\text { CCСАССССТССАТСССТGAT }\end{array}$ & 57.5 & AvaII \\
\hline $10 / 11$ & $12065-12473$ & 409 & $\begin{array}{l}\text { ATCAGTGACTTGTGCCCTCTC } \\
\text { CACCTCAAAGTGC(AC)CAAACTTC }\end{array}$ & 54.0 & AvaII \\
\hline 12 & $12569-12765$ & 197 & $\begin{array}{l}\text { CTGACTCTTTCTCTTCCCCGT } \\
\text { CTCATCCTCTCCACCCTCTG }\end{array}$ & 55.5 & - \\
\hline $13 / 14$ & $12815-13240$ & 426 & $\begin{array}{l}\text { TCCTTTTAGGGGAGGCAGAG } \\
\text { GAAGGCCCTATCCACCCTG }\end{array}$ & 54.5 & TaqI \\
\hline 15 & $14462-14656$ & 195 & $\begin{array}{l}\text { CTGTGCCTTGGCCTCTCTGT } \\
\text { GTCTGCCCTCCTGTCTCCTA }\end{array}$ & 55.5 & - \\
\hline 16 & $14725-14964$ & 240 & $\begin{array}{l}\text { GGCTCTATCCGGGCTAGG } \\
\text { TCCCTTGTCCCTTTGTGCTTG }\end{array}$ & 54.5 & - \\
\hline 17 & $15328-15171$ & 178 & $\begin{array}{l}\text { CTTTCCCTCCAACTGTCAGC } \\
\text { CTGGTGCTCATCTGCTGTCTT }\end{array}$ & 54.0 & - \\
\hline
\end{tabular}

Total-RNA was isolated from cervical precancerous and cancer tissues and control cells using the RNeasy Mini kit (Qiagen) according to the manufacturer's indications. RNA samples were treated with DNase I (Promega) and $1 \mu \mathrm{g}$ of RNA (of each sample) was reverse-transcribed with SuperScript ${ }^{\mathrm{TM}}$ II $\mathrm{RNaseH}^{-}$reverse transcriptase (Invitrogen) into cDNA using oligo(dT) primers. Real-time PCR was conducted in a Light Cycler Real-Time detection system (Roche Diagnostics) using $\mathrm{SYBR}^{\circledR}$-Green I as the detection dye. Target cDNA was quantified using the relative quantification method. The quantity of the $C C H C R l$ transcripts in each sample was standaridized by either glyceraldehyde-3-phosphate dehydrogenase (GAPDH) or RNA polymerase II (POL II) transcript levels. The RT-PCR reactions were performed in total volume of $20 \mu \mathrm{l}$. cDNA of $2 \mu \mathrm{l}$ was added to an $18 \mu \mathrm{l}$ mixture of LC-FastStart DNA Master SYBR-Green I, $1.5 \mathrm{mM} \mathrm{MgCl}_{2}$ and primers (sequence and localization of primers are given in Table III).
Statistical analysis. The results obtained were analyzed statistically. Values of the analyzed parameters, due to the quotient scale of measurement, were characterized by average value, standard deviation and median, with the lower and higher quartile providing the changeability range. Due to the diagonal distribution of the studied parameters evaluated using the Shapiro-Wilk W test for the analyses of existence of differences, non-parametric tests were used. To discover differences between the compared groups, the Kruskal-Wallis $\mathrm{H}$ test was used to compare more than two groups and the MannWhitney $U$ test to compare two independent groups. The $5 \%$ error in concluding was assumed, and $\mathrm{P}<0.05$ indicated statistically significant differences.

Methylation level analysis. Analysis of the DNA methylation level was made using the EZ DNA Methylation kit ${ }^{\mathrm{TM}}$ (Zymo Research) according to the manufacturer's indications. 
Table III. Primers used to real-time PCR study of the CCHCRl gene.

\begin{tabular}{lclc}
\hline & Fragment length & \multicolumn{1}{c}{ Primer sequence $\left(5^{\prime} \rightarrow 3^{\prime}\right)$} & Annealing temperature \\
\hline CCHCR1, F & $204 \mathrm{bp}$ & TGCGTGCTGCTTTGGCTGG & $60^{\circ} \mathrm{C}$ \\
CCHCR1, R & & CCCCTGCTCTTCTGGTTTC & \\
GAPDH, F & $106 \mathrm{bp}$ & CAATGACCCCTTCATTGACC & $60^{\circ} \mathrm{C}$ \\
GAPDH, R & & GACAAGCTTCCCGTTCTCAG & \\
POL II, F & $163 \mathrm{bp}$ & GCAAATTCACCAAGAGAGAC & $60^{\circ} \mathrm{C}$ \\
POL II, R & & ATGTGACCAGGTATGATGAG & \\
\hline
\end{tabular}

Table IV. Study groups and frequency of human papilloma virus (HPV) type 16 and/or 18 DNA occurrence.

\begin{tabular}{lccc}
\hline Group & No. of cases & HPV oncogenic types 16/18 & \% HPV positive \\
\hline L-SIL & 6 & 3 & 66.67 \\
H-SIL & 14 & 8 & 78.57 \\
Squamous cell carcinoma & 36 & 26 & 88.89 \\
Adenocarcinoma & 3 & 1 & 100 \\
Control & 18 & 0 & 0 \\
\hline
\end{tabular}

Genomic DNA (0.5-1 $\mu \mathrm{g})$ was used for the reaction of deamination. Deaminated DNA was used for the PCR reaction, with starters complementary to deaminated DNA: CCHCR1-BF 5'-TTTAAGTAGTGTTAGTTTGTG-3' and CCHCR1-BR 5'-TCTTCATCTATCCCTTCACC-3'. The PCR reactions were performed in a total volume of $10 \mu 1$. The final mixture contained $1 \mu \mathrm{M}$ primers, $200 \mu \mathrm{M}$ dNTPs, $1 \mathrm{X}$ PCR buffer, $2 \mathrm{mM} \mathrm{MgCl}_{2}$ and 1 unit FastStart TaqDNA Polymerase (Roche Diagnostics) and $2 \mu 1$ of deaminated DNA. The samples were amplified for 40 cycles. Each cycle consisted of the following steps: preliminary denaturation at $95^{\circ} \mathrm{C}$ for $5 \mathrm{~min}$, denaturation at $95^{\circ} \mathrm{C}$ for $35 \mathrm{sec}$, annealing at $56^{\circ} \mathrm{C}$ for $45 \mathrm{sec}$ and extension at $72^{\circ} \mathrm{C}$ for $1 \mathrm{~min}$. Reaction was performed in a DNA thermal cycler (Biometra). Products of amplification were analyzed on a $2 \%$ agarose gel with addition of ethidium bromide in UV transluminator. The products 675 bp long were cut out of the agarose gel, eluted with MinElute Gel Extraction kit (Qiagen), according to manufacturer's instructions and cloned into pGEM $^{\circledR}$ T-Easy Vector (Promega). DH5 $\alpha$ E. coli were transformed with recombinant $\mathrm{pGEM}^{\circledR}$ T-Easy. Clones with recombinant plasmid were selected, plasmids were isolated with QIAprep Spin Miniprep kit (Qiagen), according to the manufacturer's instructions and then sequenced.

Computer analysis. Programs MPromDb (http://bioinformatics.med.ohio-state.edu/MPromDb/index.jsp) and Cpgplot (http://www.ebi.ac.uk/emboss/Cpgplot) were used for computer analysis of the region located upstream the first transcription start site of the CCHCRI gene.

\section{Results}

In DNA probes isolated from cervical cells, HPV was detected in 32 of 36 patients with squamous cell carcinoma, 11 of 14 with H-SIL, in all of those with adenocarcinoma and none of the control group women (Table IV). In the same DNA probes the CCHCRl gene was analyzed with PCR, SSCP and sequencing methods. The changes detected in the study region are present in Table V. Changes in the sequence of the CCHCRl gene were detected in the non-coding and coding region as well. Changes in the non-coding region were found in $20.3 \%$ of the examined probes from women with cervical cancer or precancerous lesions and in $16.67 \%$ of the control probes. Most of the detected changes were SNPs. Changes in the coding region were found in $22.8 \%$ of the probes with cervical cancer and in $16.67 \%$ of the control probes. These changes were detected in exons 3, 9, 12 and 15. All of identified changes were SNPs. Six types of changes (at sites 3169, 3171, 3189 and 3356 in exon 3; 9436 and 9437 in exon 9) were connected with the amino acid change and two others changes (at sites 12622 in exon 12 and 14494 in exon 15) were not.

The mRNA CCHCR1 levels were determined by a realtime PCR method with RNA probes isolated from cervical precancerous, cancer and control cells. RT-PCR results are presented as a percentage of their controls at Fig. 1 and in Table VI. The highest $C C H C R I$ transcripts values were detected in the H-SIL group. Interestingly, $C C H C R I$ gene expression was slightly decreased in cervical carcinoma cells, compared with control probes.

According to the Kruskal-Wallis H test, statistically significant differences were found in $C C H C R I$ transcripts levels between the compared groups $(\mathrm{H}=9.06 ; \mathrm{P}=0.03$ for CCHCR1/GAPDH and $\mathrm{H}=9.23 ; \mathrm{P}=0.03$ for $\mathrm{CCHCR} 1 / \mathrm{POL}$ II). Intergroup analysis revealed differences between the control group and H-SIL and H-SIL and CA ( $\mathrm{P}=0.005$ for CCHCR1/ GAPDH and $\mathrm{P}=0.01$ for CCHCR1/POL II).

Because there is no information in the literature about the structure and function of the regulatory region of the 


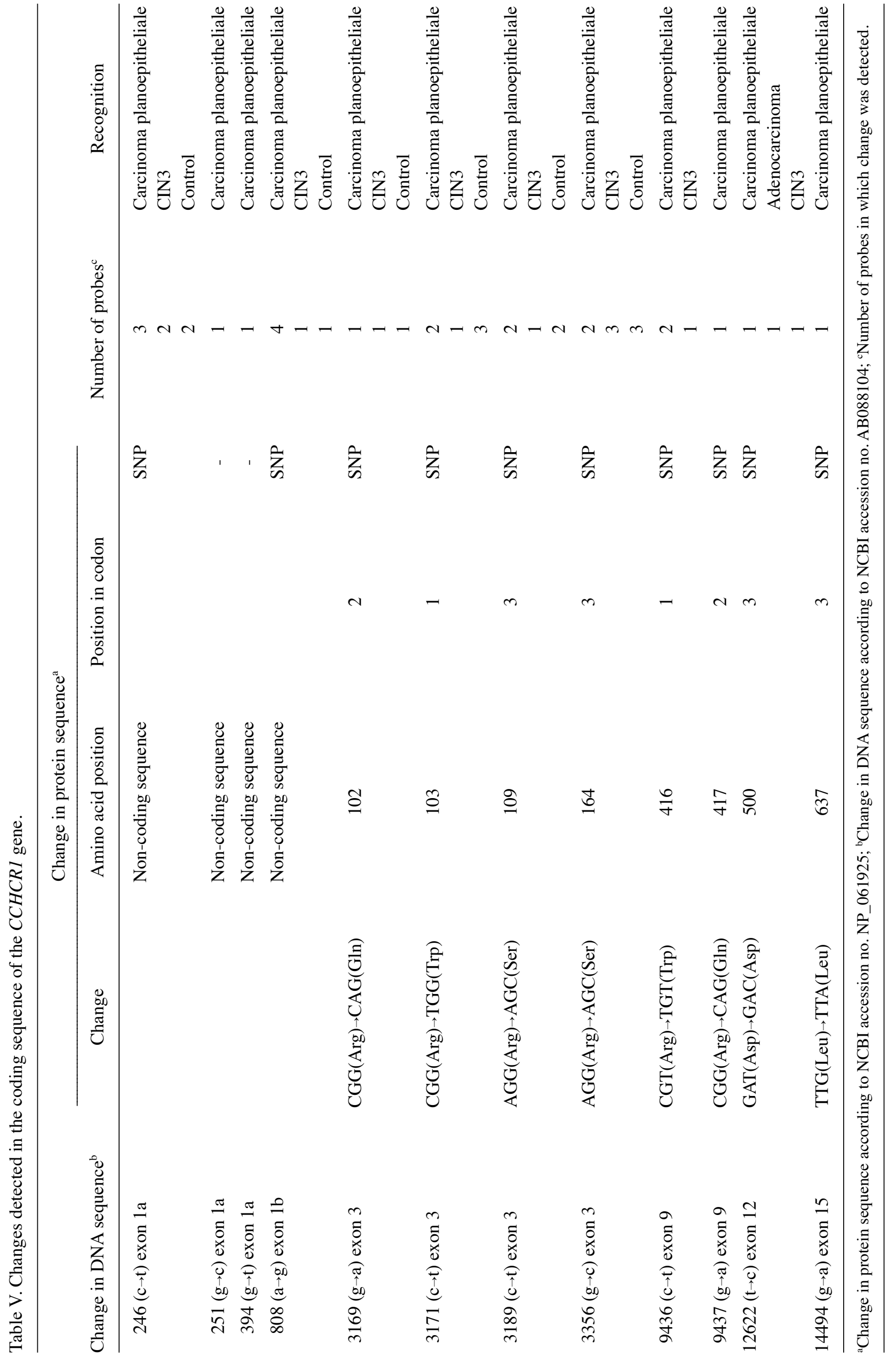


Table VI. Expression of CCHCRl gene, real-time PCR data.

A. Comparison of the CCHCR1/GAPDH values in the control, L-SIL, H-SIL and CA groups

\begin{tabular}{lllllr}
\hline Group & Mean & Median & 25th percentile & 75th percentile & Range \\
\hline Control group & 0.0061 & 0.00048 & 0.00033 & 0.00066 & $0.00032-0.034$ \\
L-SIL & 0.009 & 0.0036 & 0.00034 & 0.0123 & $0.00034-0.034$ \\
H-SIL & 0.042 & 0.036 & 0.0075 & 0.076 & $0.0065-0.090$ \\
CA & 0.0021 & 0.0015 & 0.00047 & 0.0029 & $0.00034-0.0065$
\end{tabular}

B. Comparison of the CCHCR1/POL II values in the control, L-SIL, H-SIL and CA groups

\begin{tabular}{llllrr}
\hline Group & Mean & Median & 25th percentile & 75th percentile & Range \\
\hline Control group & 0.104 & 0.0162 & 0.012 & 0.047 & $0.0104-0.524$ \\
L-SIL & 0.270 & 0.233 & 0.026 & 0.456 & $0.0245-0.649$ \\
H-SIL & 0.522 & 0.509 & 0.221 & 0.823 & $0.101-0.968$ \\
CA & 0.082 & 0.0506 & 0.022 & 0.110 & $0.00625-0.284$ \\
\hline
\end{tabular}
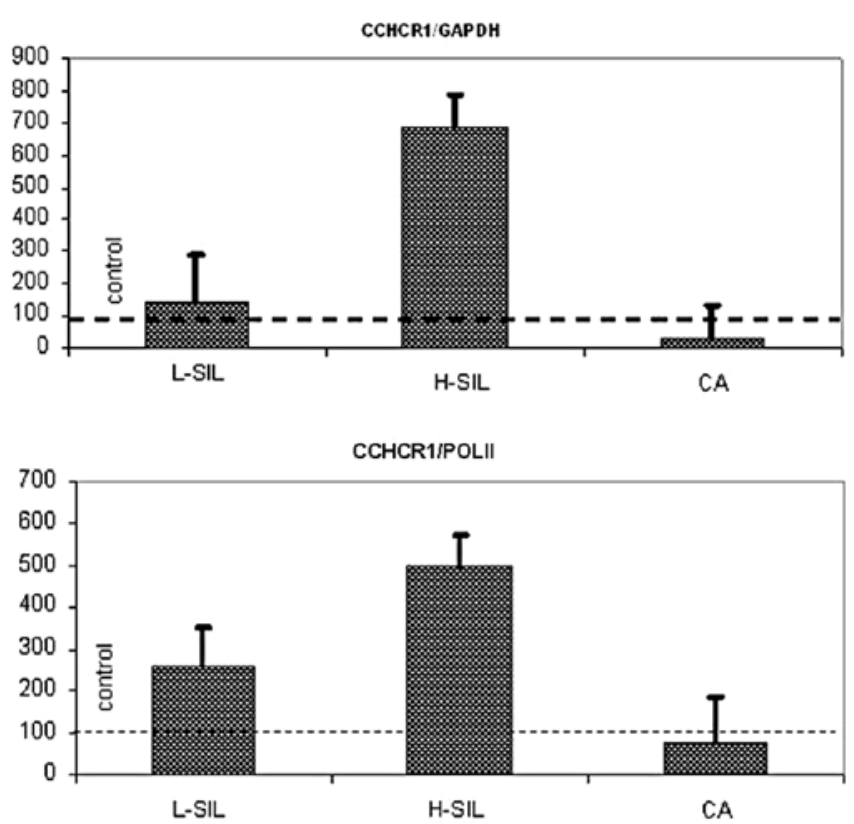

Figure 1. The expression of CCHCR1 in L-SIL, H-SIL and cervical cancer (CA) tissues. The quantity of the CCHCR1 transcripts was standardized by glyceraldehyde-3-phosphate dehydrogenase (GAPDH) and RNA polymerase II (POL II) transcript levels.

CCHCRl gene we decided to perform computer analysis of the region located upstream of the first transcription start site using the programs MPromDb and Cpgplot. We analyzed a DNA fragment about $6 \mathrm{kbp}$ long and found a $\mathrm{CpG}$ island, about $1 \mathrm{kbp}$ long, located just above first transcription start site of the CCHCR1 gene (Fig. 2).

Therefore, we performed the preliminary analysis of methylation level of the 647 bp DNA fragment with 55 CG pairs within. For this analysis we used DNA isolated from cervical epithelial cells collected from 3 healthy women (control probes) and from 3 women with carcinoma planoepitheliale.
We did not notice any differences in the DNA methylation profile in the control and cervical probes. In the analyzed DNA fragment all CG pairs were not methylated.

\section{Discussion}

The function of the CCHCR1 protein, is poorly known. It is most probably engaged in the control of epithelial cell proliferation $(4,8,13)$. It is also involved in processes like tissue-specific gene transcription (14), steroidogenesis (5) and probably metabolism of steroids (13). Suomela et al (15) have suggested that CCHCR1 plays a role in keratinocyte transformation. Our previous analysis revealed that CCHCR1 interacts with the protein E2 of the human papillomavirus type16 (HPV16) in normal cervical epithelial cells (3). E2 is the main viral regulatory protein. It plays a significant role, among other things, in regulating the expression of other viral proteins $(16,17)$.

The $C C H C R l$ gene is highly polymorphic $(4,6,10,12)$. In the genome of psoriatic persons some mutations were identified, which could probably change the secondary structure of this protein and influence its biochemical properties and antigenicity $(7,8)$. We also demonstrated that the CCHCRl gene in the non tumor and tumor cells of the cervical epithelium is highly polymorphic. Almost all detected changes, in the noncoding as well as in the coding region, were single nucleotide polymorphisms (SNPs) characterized in databases (www.ncbi. nlm.nih.gov/SNP/). Obtained results did not allow us to identify changes which were characteristic of the cervical cancer patients. Our analyses were performed in a relatively small research group and did not allow for the reliable evaluation the $C C H C R 1$ genotype frequency. It would be intentional to expand the research group to confirm or exclude if a particular genotype has a higher frequency in a population of ill women compared to a control group.

Tiala et al (13) suggest, that for the pathogenesis of such diseases like psoriasis the amount of protein produced in the cell could also be important. Very small differences in the 

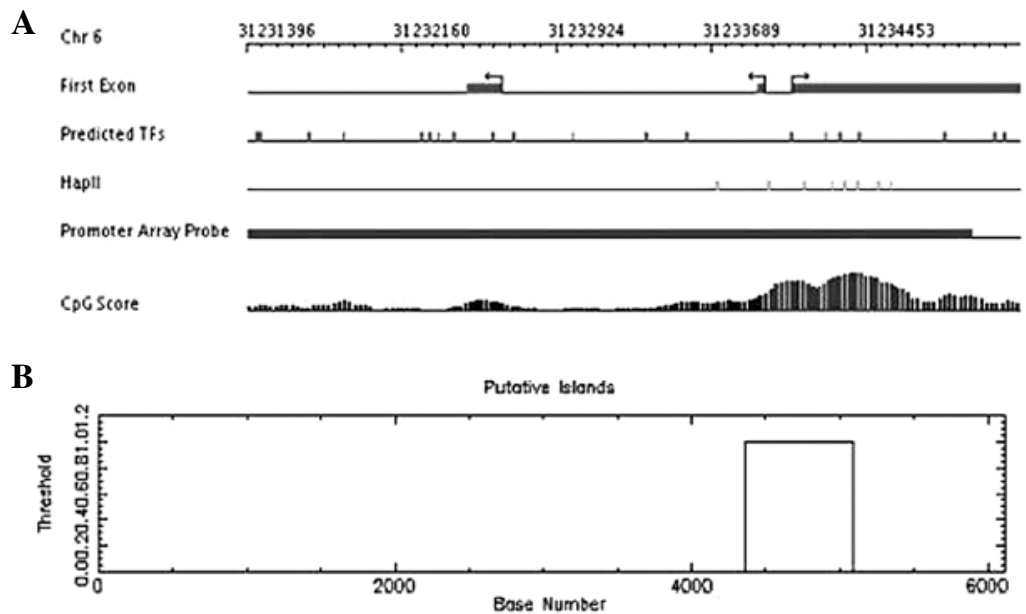

Figure 2. Computer analysis of the region located upstream of the first transcription start site of the CCHCR1 gene performed using the programs: (A) MPromDb (http://bioinformatics.med.ohio-state.edu/MPromDb/index.jsp) and (B) Cpgplot (http://www.ebi.ac.uk/emboss/Cpgplot).

experssion of the CCHCRI gene in basal kerationcytes could influence the local production of steroids $(13,18)$. SNPs in the CCHCRl gene could have an impact on the amount of produced protein, through an influence on the mRNA stability, gene expression or different regulation of this gene in response to environmental stress (13). In this context nucleotide changes in the non-coding region may have an influence on the regulation of CCHCRl gene expression, but this suggestion need to be experimentally confirmed.

CCHCR 1 gene expression analysis revealed that $C C H C R 1$ mRNA levels were higher in L-SIL and H-SIL probes compared to those in normal cervical cells. The highest CCHCR1 mRNA levels were observed in H-SIL probes, whereas the levels were lower in cervical carcinoma compared to control probes. The differences were statistically significant.

Overexpression of the CCHCRl gene could stimulate the proliferation of cervical carcinoma cells at the early stages of neoplasia. Suomela et al (15) found that proliferative cells of cutaneous squamous cell cancer (SCC) at the invasive front expressed CCHCR1, whereas the cohesive cancer cells in the middle were CCHCR1-negative. CCHCR1 expression was associated with positive EGFR staining. Cells positive for the hyperproliferation marker Ki67 were located mostly in the same areas as CCHCR1-positive cells. However, in grade III SCCs $\mathrm{Ki} 67$ was more abundantly present in cohesive tumor areas that were devoid of CCHCR1 expression. CCHCR1 expression was not induced in vitro in the most aggressive and metastatic SCC cell lines. It was also found that with ascending tumorigenicity and proliferative state, CCHCRI mRNA was downregulated in $\mathrm{HaCaT}$ cells. In contrast to benign $\mathrm{KC}$ hyperproliferation in psoriasis, the hyperproliferation marker Ki67 expresion in vivo and in vitro was associated with CCHCR1 expression in malignant transformation. CCHCR1 may participate in regulating cell proliferation only to a certain point in oncogenesis (15).

Little is known about the regulation of the CCHCRl gene expression and the structure of its regulatory region. For that reason we performed computer analysis of the region located upstream of the first transcription start site which is probably of great importance as far as the regulation of $C C H C R 1$ expression is concerned. The analysis revealed that the $\mathrm{CpG}$ island, about $1 \mathrm{kbp}$ long, is located just above the first transcription start site of the CCHCR 1 gene.

$\mathrm{CpG}$ islands are regions of higher frequency of $\mathrm{CpG}$ compared to the rest of the genome. $\mathrm{CpG}$ islands are protected from DNA methylation in normal cells, at all stages of development and in all types of tissues by mechanisms, which are poorly understood $(19,20)$. These regions function as strong promoters and can initiate DNA replication as well (19).

A lot of changes occurring in cancerous cells are caused by genetic and epigenetic abnormalities. The genome can undergo simultaneous general hypomethylation and regional hypermethylation of $\mathrm{CpG}$ islands, which can result in the occurrence of conditions leading to tumor development. This phenomenon can result in silencing of tumor suppression genes, loss of gene imprinting, and less probably, oncogene activation through demethylation, increase of the frequency of point mutations in methylated $\mathrm{CpGs}$ and instability of microsatellite DNA (20-23). However, there is no consensus as to the direct role of DNA methylation in carcinogenesis.

We analyzed the region located upstream of the first transcription start site of the CCHCRl gene. We observed no differences in the methylation level between carcinoma planoepitheliale and the normal probes. In the analyzed region all CG pairs were not methylated. Even though the analysis was carried out in few probes, we can assume that mechanisms other than methylation of the region with the probable regulatory function are responsible for the changes in $\mathrm{CCHCRI}$ mRNA levels.

Continuation of research on this subject seems to be very interesting and important, particularly in relation to the CCHCR1 and the HPV16 E2 protein interactions. Recent reports suggest that $\mathrm{CCHCR} 1$ can act as the negative regulator of keratinocyte proliferation and that inappropriate function of CCHCR1 protein can lead to incorrect keratinocyte proliferation (11) and transformation (15).

\section{Acknowledgements}

The authors would like to thank Mr. Michal Luczak, from the Department of Biochemistry and Molecular Biology, Poznan 
University of Medical Sciences, for his great help in the analysis of the methylation level of the CCHCRl gene. This study was supported by the Interdisciplinary Research Grant from the Adam Mickiewicz University and Poznan University of Medical Sciences (no. 51200 035) and a research grant from the Dean of Faculty of Biology, Adam Mickiewicz University.

\section{References}

1. zur Hausen H: Papillomaviruses and cancer: from basic studies to clinical application. Nat Rev Cancer 2: 342-350, 2002.

2. Bosch FX, Lorincz A, Munoz N, Meijer CJ and Shah KV: The causal relation between human papillomavirus and cervical cancer. J Clin Pathol 55: 244-265, 2002.

3. Olejnik-Schmidt AK, Schmidt MT, Kedzia W and GozdzickaJozefiak A: Search for cellular partners of human papillomavirus type 16 E2 protein. Arch Virol 153: 983-990, 2008.

4. Asumalahti K, Laitinen T, Itkonen-Vatjus R, Lokki ML, Suomela S, Snellman E, et al: A candidate gene for psoriasis near HLA-C, HCR (Pg8), is highly polymorphic with a disease-associated susceptibility allele. Hum Mol Genet 9: 1533-1542, 2000.

5. Sugawara T, Shimizu H, Hoshi N, Nakajima A and Fujimoto S: Steroidogenic acute regulatory protein-binding protein cloned by a yeast two-hybrid system. J Biol Chem 278: 42487-42494, 2003.

6. O'Brien K, Holm S, Nilsson S, Carlén L, Rosenmüller T, Enerbäck C, et al: The HCR gene on $6 \mathrm{p} 21$ is unlikely to be psoriasis susceptibility gene. J Invest Dermatol 116: 750-754, 2001.

7. Asumalahti K, Veal C, Laitinen T, Suomela S, Allen M, Elomaa O, et al: Coding haplotype analysis supports HCR as the putative susceptibility gene for psoriasis at the MHC PSORS 1 locus. Hum Mol Genet 11: 589-597, 2002.

8. Suomela S, Elomaa O, Asumalahti K, Arja L, Karvonen SL, Peltonen J, et al: HCR, a candidate gene for psoriasis, is expressed differently in psoriasis and other hyperproliferative skin disorders and is downregulated by interferon- $\gamma$ in keratinocytes. J Invest Dermatol 121: 1360-1364, 2003.

9. Chia NVC, Stuart P, Nair RP, Hanseler T, Jenisch S, Lim HW, et al: Variations in the HCR (Pg8) gene are unlikely to be casual for familiar psoriasis. J Invest Dermatol 116: 823, 2001.
10. Elomaa O, Majuri I, Suomela S, Asumalahti K, Jiao H, Mirzael Z, et al: Transgenic mouse models support HCR as an effector gene in PSORS1 locus. Hum Mol Genet 13: 1551-1561, 2004.

11. Tiala I, Wakkinen J, Suomela S, Puolakkainen P, Tammi R, Forsberg S, et al: The PSORS1 locus gene CCHCR1 affects keratinocyte proliferation in transgenic mice. Hum Mol Genet 17: 1043-1051, 2008

12. Chang YT, Shiao YM, Chin PJ, Liu YL, Chou FC, Wu S, et al: Genetic polymorphism of the HCR gene and a genomic segment in close proximity to HLA-C are associated with patients with psoriasis in Taiwan. Br J Dermatol 150: 1104-1111, 2004.

13. Tiala I, Suomela S, Huuhtanen J, Wakkinen J, Holtta-Vuori M, Kainu K, et al: The CCHCR1 (HCR) gene is relevant for skin steroidognesis and downregulated in cultured psoriatic keratinocytes. J Mol Med (Berl) 85: 589-601, 2007.

14. Corbi N, Bruno T, De Angelis R, Di Padova M, Libri V, Di Certo MG, et al: RNA polymerase II subunit 3 is retained in the cytoplasm by its interaction with HCR, the psoriasis vulgaris candidate gene product. J Cell Science 118: 4253-4260, 2005.

15. Suomela S, Elomaa O, Skoog T, Ala-aho R, Jeskanen L, Pärssinen J, et al: CCHCR1 is up-regulated in skin cancer and associated with EGFR expression. PloS One 4: e6030, 2009.

16. Dell G and Gaston K: Human papillomaviruses and their role in cervical cancer. Cell Mol Life Sci 58: 1923-1942, 2001.

17. Doorbar J: The papilloma life cycle. J Cin Virol 32S: S7-S15, 2005.

18. Chen W, Tsai SJ, Liao CY, Tsai RY, Chen YJ, Pan BJ, et al: Higher levels of steroidogenic acute regulatory protein and type I 3-beta-hydroxysrteroid dehydrogenase in the scalp of men with androgenetic alopecia. J Invest Dermatol 126: 2332-2335, 2006.

19. Jones PA and Takai D: The role of DNA methylation in mammalian epigenetics. Science 293: 1068-1070, 2001.

20. Jaenisch R and Bird A: Epigenetic regulation of gene expression: how the genome integrates intrinsic and environmental signals. Nat Genet 33 (Suppl): S245-S254, 2003.

21. Kalari S and Pfeifer GP: Identification of driver and passenger DNA methylation in cancer by epigenetic analysis. Adv Genet 70: 277-308, 2010.

22. Kondo Y and Issa JP: DNA methylation profiling in cancer. Expert Rev Mol Med 12: e23, 2010.

23. Kulis M and Esteller M: DNA methylation and cancer. Adv Genet 70: 27-56, 2010 